\title{
OBITUARY
}

\section{Angelo Pires do Prado (01.II.1942 - 25.VIII.2013)}

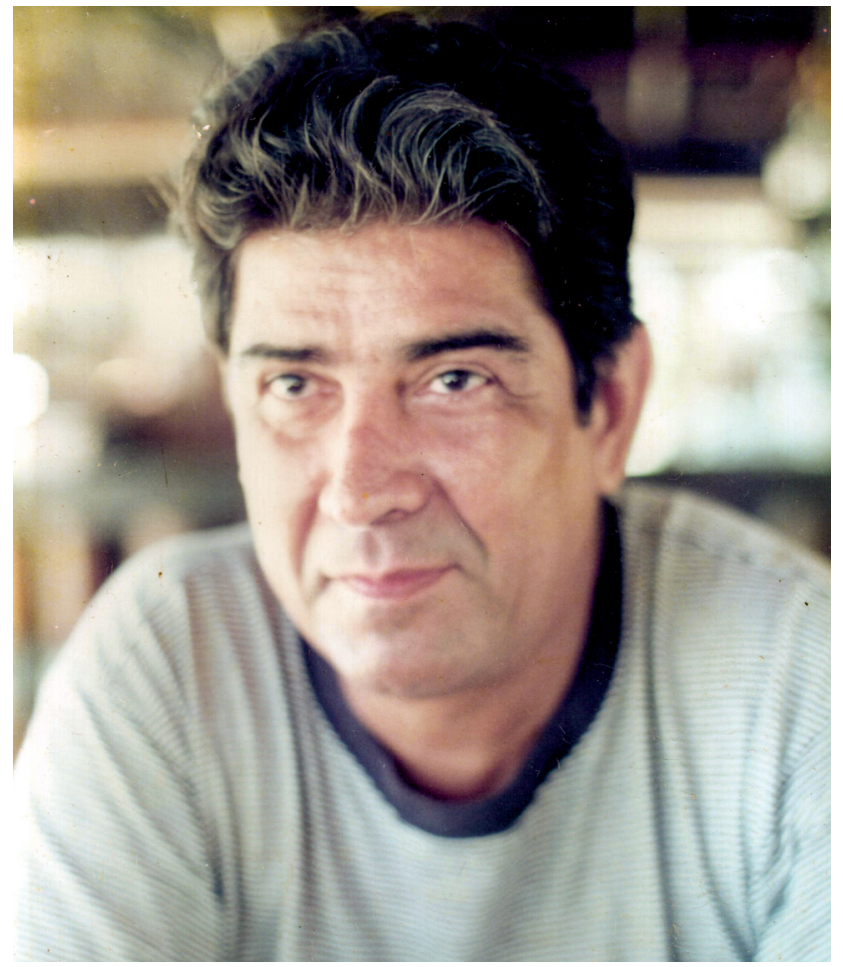

Angelo Pires do Prado was born in São Lourenço do Sul, RS (on the shore of the Laguna dos Patos) on February 1, 1942. He was the son of Antônio Pires do Prado, from Pouso Alegre, southern Minas Gerais, and Lúcia Florence Pires do Prado, from Rio Grande do Sul. Because Antônio Pires was an army officer, he was frequently deployed to different locations in Brazil. It was in Rio Grande do Sul that he met Dna. Lúcia. The couple had four children. The oldest, also named Angelo, died prematurely. He was followed by Edison (who later attended the Universidade Federal Rural do Rio de Janeiro and earned a degree in agronomy), Áureo and finally, Angelo Pires do Prado, the youngest (Edison and Áureo were eight and four years older than Angelo, respectively). In 1944, the family moved to Rio de Janeiro.

After completing his basic education in the former nations' capital, attending elementary school at the Colégio São João and middle school at the Colégio Cristo Rei, Angelo was accepted by the technical school Escola Agrotécnica Ildefonso Simões Lopes, where he was a student from 1958 to 1960. There, his interest in entomology was born.
Angelo Pires do Prado nasceu em São Lourenço do Sul, RS (às margens da Laguna dos Patos) no dia $1^{\circ}$ de fevereiro de 1942, filho de Antônio Pires do Prado, originário de Pouso Alegre, no sul de Minas Gerais, e de Lúcia Florence Pires do Prado, gaúcha. Antônio Pires era militar, sendo frequentemente designado para servir em vários locais do Brasil. Foi no Rio Grande do Sul que conheceu Dna. Lúcia. O casal teve quatro filhos - o mais velho, que também foi chamado Angelo, morreu prematuramente; vieram depois Edison (que se formaria em agronomia pela Universidade Federal Rural do Rio de Janeiro) e Áureo, sendo o nosso Angelo, o caçula (Edison e Áureo eram oito e quatro anos mais velhos que ele, respectivamente). Em 1944 a família mudou-se para o Rio de Janeiro.

Após fazer seus estudos básicos na então capital federal o primário no Colégio São João e o ginásio no Colégio Cristo Rei, Angelo passou para a Escola Agrotécnica Ildefonso Simões Lopes, a qual frequentou de 1958 a 1960. Ali, seu interesse pela entomologia foi despertado. 
Angelo was granted admission to the veterinary school of the Universidade Federal Rural do Rio de Janeiro (UFRRJ) in 1961, graduating in 1964. He received a Scientific Initiation fellowships from the Instituto de Economia Rural do Ministério da Agricultura (1962) and from the Conselho Nacional de Pesquisas (CNPq, 1963-1964). In 1962, he published a paper on a Nemertine parasitizing dogs and in 1963 a paper on the occurrence of a mite on Gallus gallus domesticus.

While he was still a student, Angelo was offered an internship at the Instituto Oswaldo Cruz to work with Prof. Dr. Hugo Souza Lopes, who was a professor at the UFRRJ. There Angelo specialized in Diptera, becoming one of the finest acalyptrate Diptera specialists in Brazil. He later joined the institute as a candidate ("Aplicante") and remained there from 1965 to 1966 (in 1965 he was granted a Specialization Fellowship from the Conselho Nacional de Pesquisas). His first papers on Diptera (Ropalomeridae, 1963, 1965, 1967; Richardiidae, 1965; Tethinidae, 1966) were excellent and revealed his extraordinary abilities and competence.

During this period, in 1965, Prof. Dr. Zeferino Vaz was appointed president of the organization committee that orchestrated building the Unicamp campus, which was subsequently named after him. Zeferino invited researchers from many institutions to work at Unicamp, which became one of the most respected and productive institutions in Latin America. In 1966, Prof. Vaz created the Parasitology branch of the Faculdade de Ciências Médicas de Campinas.

Angelo was first hired as an instructor, and in May of that same year he was appointed Assistant Professor. In 1968, Parasitology was the first department to be transferred to the current university campus, in the suburb of Barão Geraldo. Angelo was one of the first to teach at the new campus.

Angelo married Marisa Benedita de Alvarenga Silva in 1968, and the couple had a child, Angelo Alvarenga Prado, who died in 2003.

In 1969, under Prof. Dr. Hugo de Souza Lopes, Angelo defended his Ph.D. dissertation. His work ("Syringogastridae, uma nova família de dípteros Acalyptratae, com a descrição de seis espécies novas do gênero Syringogaster Cresson", published in the same year by Studia Entomologica (12: 1-32)) marked the history of phylogenetic systematics in Latin America. Willi Hennig had published (1965) an abstract of his theory (Annual Review of Entomology 10: 97-116) and the English version of his Phylogenetic Systematics came out in 1966. Lars Brundin, also in1966, was the first to publish a large revision (of a group of Chironomidae) using Hennigian principles, and Angelo, with his acute intelligence, was undoubtedly the first in Brazil to understand Hennig's principles and to apply his theory, using it to erect a new family, Syringogastridae.

In the years that followed, Angelo published only sporadic contributions on Diptera - in 1975 he produced an elegant paper on Odiniidae (Stephen Gaimari recognized his contribution by naming a new genus after him, Pradomyia).
Ingressou então na Escola Nacional de Veterinária da Universidade Federal Rural do Rio de Janeiro (UFRRJ) em 1961, graduando-se em 1964. Foi bolsista de Iniciação Científica do Instituto de Economia Rural do Ministério da Agricultura (1962) e do Conselho Nacional de Pesquisas (CNPq, 1963-1964). Em 1962 publicou artigo sobre um nemertino parasito do cão e, em 1963, sobre a ocorrência de um ácaro em Gallus gallus domesticus.

Durante seus anos como estudante foi convidado pelo Prof. Dr. Hugo Souza Lopes, docente da UFRRJ, a estagiar no Instituto Oswaldo Cruz, especializando-se no estudo dos Diptera, principalmente Acalyptratae, dos quais veio a tornarse o mais exímio especialista do Brasil. Ingressou no Instituto como "Aplicante", ali permanecendo nos anos de 1965 e 1966 (em 1965 obteve bolsa de Aperfeiçoamento do Conselho Nacional de Pesquisas). Datam desse período seus primeiros e primorosos trabalhos sobre Diptera (Ropalomeridae, 1963, 1965, 1967; Richardiidae, 1965; Tethinidae, 1966), nos quais já demonstrava sua extraordinária habilidade e competência.

Durante esse período, em 1965, fora designado presidente da Comissão Organizadora da Unicamp o Prof. Dr. Zeferino Vaz que conduziu a construção do campus da universidade, que hoje leva seu nome. Zeferino trouxe diversos cientistas de outras universidades, o que ajudou a Unicamp a se tornar um das mais produtivas e respeitadas instituições de pesquisa da América Latina. Em 1966 o Prof. Vaz criava a disciplina de Parasitologia junto à Faculdade de Ciências Médicas de Campinas.

Angelo foi contratado em 1967, como Instrutor, passando em maio desse mesmo ano a Professor Colaborador. Foi este o início de sua carreira docente. Em 1968, a Parasitologia foi o primeiro Departamento da Unicamp a transferir-se para o atual Campus da Universidade, na atual Cidade Universitária, em Barão Geraldo. Angelo foi um dos pioneiros no novo campus.

Em 1968, Angelo casou-se com Marisa Benedita de Alvarenga Silva, de cuja união nasceu Angelo Alvarenga Prado, o primeiro filho, falecido em 2003.

Em 1969 Angelo defendeu na Unicamp sua tese de doutorado, tendo como orientador o Prof. Dr. Hugo de Souza Lopes. Esse trabalho ("Syringogastridae, uma nova família de dípteros Acalyptratae, com a descrição de seis espécies novas do gênero Syringogaster Cresson", publicado nesse mesmo ano em Studia Entomologica (12: 1-32)) representa um marco na história da Sistemática Filogenética na América Latina. Willi Hennig havia publicado em 1965 (Annual Review of Entomology 10: $97-$ 116) um resumo de sua teoria e, em 1966, era lançada a versão em inglês de seu clássico livro Phylogenetic Systematics. Lars Brundin, também em 1966, foi o primeiro a publicar uma grande revisão (de um grupo de Chironomidae) utilizando os princípios hennigianos. Angelo, com sua aguda inteligência, foi sem dúvida o primeiro no Brasil a entender e aplicar a teoria de Hennig, erigindo a nova família Syringogastridae.

Nos anos seguintes Angelo passou a publicar trabalhos sobre a sistemática de Diptera de modo esporádico - em 1975 publicou um belo trabalho sobre Odiniidae (Stephen Gaimari 

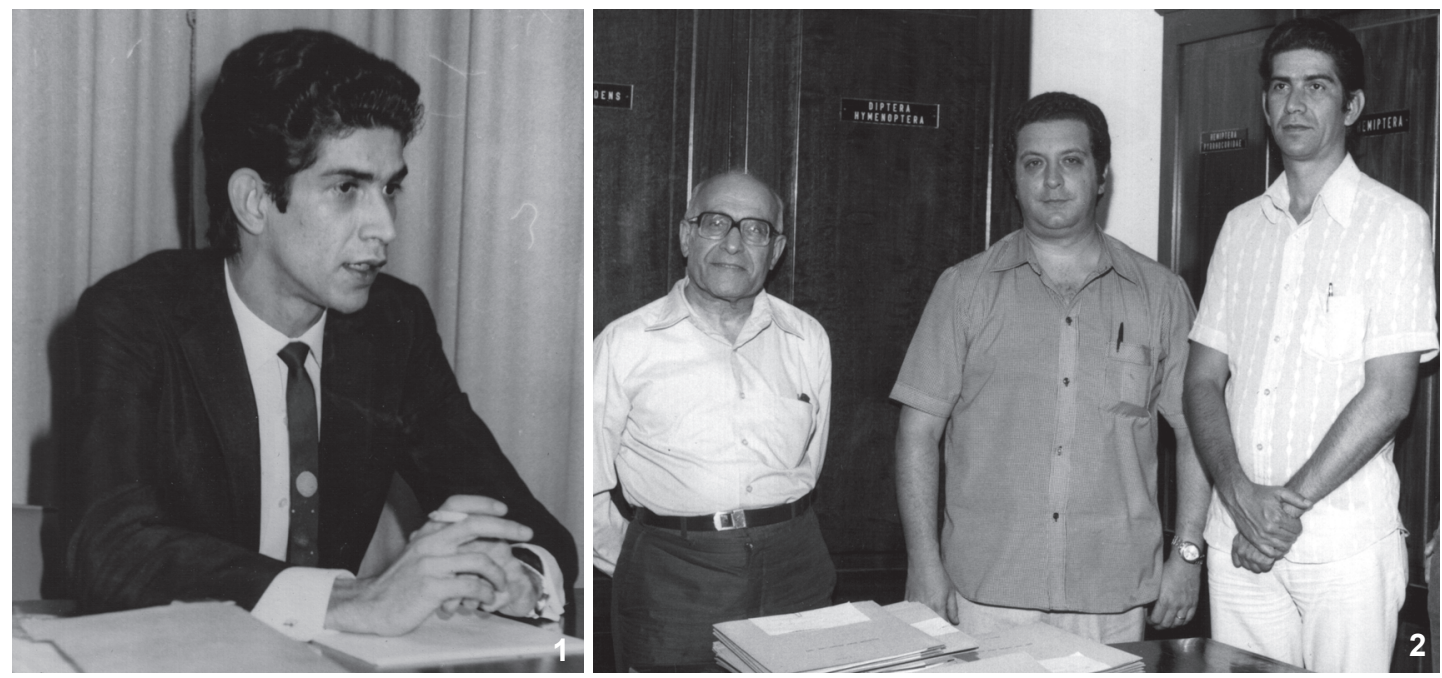

Figures 1-2. Angelo Pires do Prado during his Ph.D. defense, Universidade Federal Rural do Rio de Janeiro, 07.III.1969. (2) Jesus Santiago Moure, Nelson Papavero and Angelo Pires do Prado, 1979.

Also in 1975, Angelo organized several chapters, all on acalyptrate families, for the Catalogue of the Diptera of the Americas South of the United States series. During this period I acquired the reprints and the phorid collection from Frei Thomaz Borgmeier, to be incorporated to the collection of the Museu de Zoologia da Universidade de São Paulo. José Henrique Guimarães, Renato Lion Araujo and Angelo Pires do Prado transported the material from Petrópolis to São Paulo. Subsequently, Angelo published two contributions on Phoridae, in 1975 and 1976.

In 1977, thanks to FAPESP, Angelo organized the acalyptrate fly collection of the Museu de Zoologia. One year latter (1978), he collaborated with José Henrique Guimarães and Arício Xavier Linhares on a historic paper about the introduction of species of Chrysomyia (Calliphoridae) in Brazil. This was the first of a series of scientific contributions on the genus involving researchers from various institutions, some of which are still being published.

Thanks to two assistantships granted by CNPq, father Jesus Santiago Moure, Angelo Pires do Prado and I formed a committee to investigate and write a report on the status of zoology in Brazil. We visited the main institutions in the country, collected CVs from zoologists, and made an inventory of the collections. Unfortunately, CNPq did not use our database. I gave our committee the nickname "Celestial Committee", because it was composed of a Jesus, an Angel, and a Papa... (meaning "Pope" in Portuguese.)

In 1982, Angelo married again. His new wife, Yara Valença da Rocha Prado, was a former biology student who ended up majoring in law. The couple had two children, Laura Rocha Prado (biology major from Unicamp) and Renato Rocha Prado (rural producer). dedicou-lhe, em 2007, um novo gênero dessa família, Pradomyia, em reconhecimento da excelência de sua revisão desse grupo). Nesse mesmo ano, elaborou vários catálogos de famílias de Acalyptratae para a série Catalogue of the Diptera of the Americas South of the United States.

Por essa época, eu adquiri a coleção e a bibliografia de Phoridae do Frei Thomaz Borgmeier para o Museu de Zoologia da Universidade de São Paulo. Esse material foi trazido de Petrópolis para o Museu por José Henrique Guimarães, Renato Lion Araujo e Angelo Pires do Prado. Este último viria a publicar dois trabalhos sobre Phoridae em 1975 e 1976.

Em 1977, graças a auxílio da FAPESP, Angelo organizou a coleção de Acalyptratae do Museu de Zoologia da USP.

Em 1978, publicou, com a colaboração de José Henrique Guimarães e Arício Xavier Linhares, um histórico trabalho sobre a introdução de espécies de Chrysomyia (Calliphoridae) no Brasil. Foi o início de uma grande série de trabalhos sobre esse gênero, feitos tanto por esses autores, como por vários outros de outras instituições, até os presentes dias.

Em 1979, graças a dois auxílios do CNPq, foi formada uma comissão composta pelo Pe. Jesus Santiago Moure, Angelo Pires do Prado e eu, para fazer um levantamento da situação da Zoologia em nosso país. Foram visitadas as principais instituições do Brasil, obtidos os currículos dos zoólogos e inventariadas as diversas coleções. Infelizmente toda essa base de dados não foi aproveitada pelo CNPq. Eu apelidei nosso grupo de "Celestial Comissão", pois contava com um Jesus, um Anjo e um Papa...

Em 1982 casou-se, em segundas núpcias, com Yara Valença da Rocha Prado, sua ex-aluna na faculdade de Biologia e, posteriormente, formada em Direito. Tiveram dois filhos, Laura Rocha Prado (bióloga formada pela Unicamp) e Renato Rocha Prado (produtor rural). 
In 1983, Guimarães, Papavero \& Prado published a contribution on Neotropical myiases in the first volume of the Revista Brasileira de Zoologia. In the years that followed, Angelo began to focus more on parasitology, particularly entomological parasitology, vectors and plant health, besides insecticide resistance. His main contributions were on Musca domestica, synantropic Diptera, development and ecology of domestic flies, fruit flies and blowflies, domestic mites (dust mites), phytophagous mites, mites associated with synanthropic and wild birds (nest, feather and skin mites.)

Angelo authored several catalogs of Acalyptratae Diptera for the series Fauna da Amazônia Brasileira, edited by the Museu Paraense Emílio Goeldi, and for the Neotropical Diptera series

During his professional life, Angelo published 117 scientific contributions and one book. He advised 35 Master of Science students to the completion of their theses (1979-2011). Two additional theses from that same period are ongoing. Seventeen Ph.D. dissertations were completed under his mentorship, and seven more are ongoing (1976-2011). Additionally, he participated in 139 dissertation committees (Master and Ph.D.)

Despite the terrible illness that fell upon him, and the fact that he was constrained to retire, Angelo continued to contribute to the Unicamp as an associate professor. He was loyal, wise, objective, ethical and generous. Angelo opened many doors for the research of others and never asked for anything in return.

\section{ACKNOWLEDGEMENTS}

I thank Yara Valença da Rocha Prado and Laura Rocha Prado, for providing important data, and Dr. Sionei R. Bonatto, for inviting me to write this obituary.
Em 1983, no primeiro volume da Revista Brasileira de Zoologia, Guimarães, Papavero \& Prado publicaram um trabalho sobre as miíases da região neotropical.

Nos anos subsequentes, Angelo dedicou-se cada vez mais a assuntos de Parasitologia, com ênfase em entomologia de parasitos e vetores e sanidade vegetal, além de resistência a inseticidas, atuando principalmente nos seguintes temas: Musca domestica, dípteros sinantrópicos, desenvolvimento e ecologia de moscas domésticas, de frutas e varejeiras, ácaros domésticos (de poeira), ácaros fitófagos, ácaros associados às aves sinantrópicas e silvestres (nidícolas, plumícolas, calamícolas e da pele). Colaborou com vários catálogos de Acalyptratae para a série Fauna da Amazônia Brasileira, editada pelo Museu Paraense Emílio Goeldi e com vários artigos para a série Neotropical Diptera.

Ao longo de sua vida profissional, Angelo publicou 117 artigos científicos e um livro. Orientou 35 dissertações de Mestrado, terminadas (1979-2011). Em andamento, do mesmo período, há duas. As de Doutorado foram 17 terminadas e há sete ainda em andamento (1976-2011). Participou de 139 bancas examinadoras (mestrado e doutorado).

Mesmo contrariado pelo fato de ter que se aposentar compulsoriamente, permaneceu ativo na Unicamp na qualidade de professor associado, apesar da terrível doença que o vitimou. Era leal, sensato, objetivo, ético, generoso; abria frentes de pesquisa para que outros continuassem, sem nada exigir em troca.

\section{AGRADECIMENTOS}

A Yara Valença da Rocha Prado e Laura Rocha Prado, por sua gentileza em fornecer importantes dados e ao Dr. Sionei R. Bonatto, pelo convite para redigir este obituário.

\section{Nelson Papavero}

Museu de Zoologia, Universidade de São Paulo. Avenida Nazaré, 481, 04263-000 São Paulo, SP, Brazil. 